\title{
Продуктивность и морфолого- биохимические характеристики инкубационных яиц отечественных пород индеек
}

Погодаев В.А., доктор сельскохозяйственных наук, профессор, главный научный сотрудник ФГБНУ «Северо-Кавказский федеральный научный аграрный центр»

Буравцова И.Н., старший научный сотрудник - старший ветеринарный врач зооветеринарной лаборатории Романенко И.В., научный сотрудник отдела селекции и генетики

Колобова О.Е., младший научный сотрудник отдела селекции и генетики

Селекционно-генетической центр «Северо-Кавказская зональная опытная станция по птицеводству» (СГЦ «СКЗОСП») - филиал ФНЦ «ВНИТИП» РАН

\begin{abstract}
Аннотащия: Целью настоящей работы ябилось определение продуктибных особенностей, морфологических и биохимических характеристик инкубационных яиц, переярых индеек биоресурсной коллекции 6 начале, середине и коние продуктивного периода при групповом учете. Исследования проводились 6 произбодственных условиях СГЦ «СКЗОСП» на индейках биоресурсной коллекции: шести пород основного генофонда и четырех популяций нового генофонда - голубых, красных и групп 602 и 607. Установлено, что средняя живая масса переярых индеек основного генофонда 6 начале яйцекладки пребосходила стандартные значения. Наиболее бысокая масса яии (83,07 г) отмечена у бронзобой себерокабказской породы. Индекс форми яии у индеек генофонда находился 6 переделах 68,53-72,93\%. Единицы Хау 6 бо всех породах находились 6 пределах 92,93-94,73\%, соответствуя стандарту. Содержание битамина $B_{2} G$ белке яии было 6 пределах нормы у бронзовой себерокабказской и узбекской палебой пород; пребышение норматива наблюдалось у белой себерокабказской (на 0,43 мкг/2), московской белой (на 0,67 мкг/2) и черной тихорецкой (на 0,75 мкг/2) пород. Лучший показатель по жибой массе 616 недель отмечен у белой себерокабказской (5,54 кг) и московской белой (5,63 кг) пород; 6 этих же породах самцы имели бысокую мясную оценку (от 4,47 до 4,55 балла). Живая масса индюшат-сами,ов в группе 607 составила 5,98 кг.
\end{abstract}

Ключебые слова: индейки, породы, геноронд, продуктивность, инкубационные яйца, морфология яии, биохимический состав яии.

Введение. Анализ развития отечественного производства мяса индеек с 2014 по 2019 гг. показывает, что рост производства мяса в убойном весе составил 178,49 тыс. т, что превышает темпы роста производства мяса свинины на 5, $1 \%$, говядины - на $0,8 \%$. При этом годовое потребление индюшатины на душу населения составляет 1,97 кг. По данным консалтингового агентства «АГРИФУД Стретеджис» [1], дальнейшее развитие отрасли объясняется повышенным спросом на индюшатину в России, связанным с ее диетически- ми свойствами, разнообразной текстурой, низким содержанием жира и высоким уровнем белка. Помимо растущей популярности у отечественных потребителей мясной продукции из индеек, идет расширение ее экспорта, который, как ожидается, составит к 2025 г. 30 тыс. т при объеме внутреннего производства 550 тыс. т.

В СГЦ «СКЗОСП» постоянно проводится селекционно-племенная работа, направленная на совершенствование существующих и создание новых высокопродуктивных генотипов индеек [2-4]. Поэто- му сравнительное изучение продуктивности индеек отечественных пород биоресурсной коллекции является актуальной задачей.

Целью настоящей работы явилось определение продуктивных особенностей, морфологических и биохимических характеристик яиц переярых индеек биоресурсной коллекции в начале, середине и конце продуктивного периода при групповом учете.

Материал и методика исследований. Исследования проводились в 2019 г. в производственных условиях СГЦ «СКЗОСП», с. Обиль- 
ное Ставропольского края. Объектом исследования служили переярые индейки биоресурсной коллекции ЦКП шести пород основного генофонда: бронзовой северокавказской, белой северокавказской, серебристой северокавказской, московской белой, узбекской палевой, черной тихорецкой, а также четырех популяций нового генофонда: голубых, красных и групп 602 и 607.

Все породы основного генофонда внесены в Государственный реестр селекционных достижений [5]. При проведении эксперимента руководствовались методикой [6] и техническими условиями «яйца индеек инкубационные» [7]. Бонитировку ремонтного молодняка индеек проводили согласно инструкции [8].

Индеек всех половых и возрастных групп кормили кормосмесями, приготовленными по рекомендациям ВНИТИП и разработкам СКЗОСП [9-11]. Инкубационные яйца из корпусов поступали для сортировки на центральный яйцесклад, где производился отбор проб яиц в соответствии с требованиями ТУ 2015 г. [7]. Определение морфологических и биохимических показателей яиц проводили в зооветеринарной лаборатории СГЦ «СКЗОСП» согласно методическим указаниям [12].

Результаты исследований и их обсуждение. Продуктивность основной хозяйственно-полезный признак птицы, имеющий достаточно высокую степень изменчивости. Яйценоскость отечественных индеек колеблется в широких пределах. Например, у всех северокавказских пород яйценоскость за один племенной сезон составляет 75-78 яиц, а годовая от 118 до 125 шт. Имеются группы индеек с яйценоскостью 160 яиц, а рекордистки дают более 220 яиц в год [13].

Начало яйцекладки у индеек наступает в возрасте 7-8,5 месяцев, в зависимости от породной принадлежности. Физиологическая скороспелость - это генетически обусловленный фактор, свойственный данному виду птицы, породе, линии. Этот признак является высоко наследуемым, причем на его наследование преимущественное влияние оказывает отцовский организм [14].

Данные, представленные в табл. 1, дают общее представление о продуктивных качествах переярых индеек в период яйцекладки в сравнении со стандартными показателями.

Установлено, что средняя живая масса переярых индеек основного генофонда в начале яйцекладки превосходила стандартные значения. Так, узбекская палевая порода превосходила стандартные показатели на 13,84\%; белая северокавказская - на 11,05\%; московская белая - на 8,96\%; черная тихорецкая - на 10,2\%; серебристая северокавказская - на
2,20\%. Исключением являлась бронзовая северокавказская порода, чья живая масса в начале яйцекладки была ниже стандартного показателя на 4,31\%.

Macca яйца является вторым главным селекционным признаком, который имеет важное экономическое значение при производстве яичной продукции. Основной фактор, влияющий на массу яйца - это возраст несушки. Поскольку масса яиц в зависимости от периода яйцекладки и возраста птицы изменяется, чтобы комплексно оценить индеек по продуктивности за определенный период, рассчитывают показатели массы яиц.

Масса яиц переярых индеек бронзовой северокавказской породы в начале яйцекладки была на 1,63 г или на 2,09\% ниже среднего периода продуктивности и на 5,4 г или 6,95\% ниже, чем в конце яйцекладки. Начальная масса яиц у белой северокавказской породы была ниже на 10,94 г или на 15,24\% показателей среднего периода и ниже конечного периода продуктивности на 8,93 гили на 12,44\%; однако масса яиц на конец яйцекладки снижалась по отношению к среднему периоду на 2,01 г или на 2,49\%. Масса яиц у серебристой северокавказской породы за весь период варьировала: в 10 недель был зафиксирован максимальный показатель - 82,70 г, что выше начального уровня на 10,94 г или

\begin{tabular}{|c|c|c|c|c|c|}
\hline \multirow{2}{*}{ Породы } & \multirow{2}{*}{$\begin{array}{c}\text { Маркировка } \\
\text { групп }\end{array}$} & \multirow{2}{*}{$\begin{array}{l}\text { Живая масса } \\
\text { в начале яй- } \\
\text { цекладки, кг }\end{array}$} & \multicolumn{3}{|c|}{$\begin{array}{c}\text { Масса яиц по периодам } \\
\text { продуктивности, г }\end{array}$} \\
\hline & & & $\begin{array}{c}3 \text { неделя } \\
\text { (начальный) }\end{array}$ & $\begin{array}{l}10 \text { неделя } \\
\text { (средний) }\end{array}$ & $\begin{array}{l}17 \text { неделя } \\
\text { (конечный) }\end{array}$ \\
\hline Бронзовая северокавказская & 161 & $5,564 \pm 0,08$ & $77,67 \pm 0,95$ & $79,30 \pm 0,75$ & $83,07 \pm 2,21$ \\
\hline Белая северокавказская & 162 & $6,333 \pm 0,08$ & $71,76 \pm 1,13$ & $82,70 \pm 0,74$ & $80,69 \pm 2,45$ \\
\hline Серебристая северокавказская & 163 & $6,037 \pm 0,12$ & $71,70 \pm 1,11$ & $78,50 \pm 0,68$ & $75,92 \pm 1,50$ \\
\hline Московская белая & 164 & $6,327 \pm 0,06$ & $69,78 \pm 0,84$ & $80,50 \pm 0,78$ & $81,38 \pm 1,58$ \\
\hline Узбекская палевая & 165 & $5,920 \pm 0,11$ & $69,78 \pm 0,89$ & $77,40 \pm 0,74$ & $80,09 \pm 1,69$ \\
\hline Черная тихорецкая & 166 & $5,511 \pm 0,08$ & $74,70 \pm 2,91$ & $79,30 \pm 0,67$ & $81,70 \pm 1,37$ \\
\hline
\end{tabular}


15,24\%, и конечного - на 2,01 г или на 2,49\%. Московская белая и узбекская палевая породы имели наименьшую массу яйца на начало яйцекладки по отношению ко всем породам основного генофонда - 69,78 г. Этот низкий показатель постепенно увеличивался к середине яйцекладки на 10,72 и 7,62 г или на 15,36 и $10,92 \%$ соответственно, а к концу продуктивного периода - на 11,6 и 10,31 гили на 16,62 и 14,77\% по отношению к начальной массе яиц. Масса яиц у черной тихорецкой породы на начало продуктивного периода составила 74,70 г, что ниже показателей средней массы яиц в середине яйцекладки на 4,6 г или на 6,15\% и конечного периода продуктивности - на 7,0 г или на 9,37\%.

Анализируя полученные результаты, можно отметить, что увеличение срока использования переярых индеек-несушек позволяет шире раскрыть генетический потенциал продуктивности птицы.

Взвешивание яиц переярых индеек основного генофонда показало, что средняя масса яйца в начале яйцекладки была несколько ниже всего периода продуктивности. Затем при стабилизации яичной продуктивности масса яйца стала постепенно увеличиваться. В конце продуктивного периода средней массой одного яйца по ТУ [7] считается диапазон 65-95 г, что полностью соответствует показателям массы яиц по породам индеек основного генофонда.

Изучение морфологических и биохимических показателей яиц переярых индеек биоресурсной коллекции ЦКП проводили при групповом учете (табл. 2). Наиболее высокая масса яиц отмечена у бронзовой северокавказской породы и составила 83,07 г, что выше, чем у белой северокавказской породы на 2,38 г (2,86\%); серебристой северокавказской породы на 7,15 г (8,61\%); московской белой породы - на 1,69 г (2,03\%); узбекской палевой породы - на 2,98 г (3,59\%) и черной тихорецкой породы - на 1,37 г (1,65\%).

Точной характеристикой формы яиц как важного показателя, влияющего на положение эмбриона в процессе его развития, является индекс формы. Индекс формы в значительной степени связан с количеством боя и насечки яиц, по нормативу он должен составлять 70-76\%.

В наших исследованиях индекс формы яиц переярых индеек генофонда находился в пределах 68,53-72,93\%. Наибольшие показатели индекса формы яиц были отмечены в белой северокавказской, серебристой северокавказской и московской белой породах. Индекс формы яиц индеек белой северокавказской породы превышал этот показатель у бронзовой северокавказской породы на 4,4\%, у серебристой северокавказской - на 2,8\%, у московской белой - на 1,86\%, узбекской палевой - на 4, 1 3\%, у черной тихорецкой породы - на 3,06\%.

Самую высокую связь с индексом формы по качеству белка имеют единицы Хау. Во всех породах этот показатель находился в пределах 92,93-94,73\%, соответствуя стандарту (не менее 80\%).

Толщина скорлупы яиц определяет их прочность и сопротивление механическим воздействиям. Яйца индеек бронзовой северокавказской, белой северокавказской, серебристой северокавказской пород по этому показателю находились в пределах стандартных значений. Ниже стандарта было значение у московской белой (на 0,02 мм), узбекской палевой (на 0,006 мм), черной тихорецкой (на 0,003 мм) пород, хотя отличия от стандарта были незначительными.

Изучение биохимических показателей яиц переярых индеек показало, что содержание витамина $B_{2}$ в белке яиц находилось в пределах нормы у бронзовой северокавказской и узбекской палевой пород; превышение норматива наблюдалось у белой се-

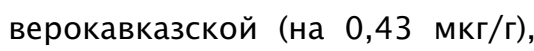
московской белой (на 0,67 мкг/г) и у черной тихорецкой на $(0,75$ мкг/г) пород. Незначительное отклонение от стандарта (на 0,04

\begin{tabular}{|c|c|c|c|c|c|c|c|}
\hline \multirow[b]{2}{*}{ Показатель } & \multirow[b]{2}{*}{$\begin{array}{c}\text { Норма } \\
\text { по Ty }\end{array}$} & \multicolumn{6}{|c|}{ Породы индеек } \\
\hline & & $\begin{array}{c}\text { Бронзовая } \\
\text { северокав- } \\
\text { казская }\end{array}$ & $\begin{array}{c}\text { Белая } \\
\text { северокав- } \\
\text { казская }\end{array}$ & $\begin{array}{c}\text { Серебристая } \\
\text { северокав- } \\
\text { казская }\end{array}$ & $\begin{array}{l}\text { Московская } \\
\text { белая }\end{array}$ & $\begin{array}{c}\text { Узбекская } \\
\text { палевая }\end{array}$ & $\begin{array}{c}\text { Черная } \\
\text { тихорецкая }\end{array}$ \\
\hline Масса яиц, г $(n=10)$ & $65-95$ & $83,07 \pm 2,21$ & $80,69 \pm 2,45$ & $75,92 \pm 1,50$ & $81,38 \pm 1,58$ & $80,09 \pm 1,69$ & $81,70 \pm 1,37$ \\
\hline Индекс формы, \% $(n=5)$ & $70-76$ & $68,53 \pm 1,54$ & $72,93 \pm 0,45$ & $70,13 \pm 1,10$ & $71,07 \pm 1,33$ & $68,80 \pm 0,58$ & $69,87 \pm 0,96$ \\
\hline Единицы Хау, \% (n= 5) & не менее 80 & $94,40 \pm 0,75$ & $94,13 \pm 0,81$ & $94,73 \pm 0,19$ & $93,40 \pm 0,93$ & $94,73 \pm 0,49$ & $92,53 \pm 0,39$ \\
\hline Толщина скорлупы, мм & $0,320-0,340$ & 0,334 & 0,330 & 0,321 & 0,300 & 0,314 & 0,317 \\
\hline $\begin{array}{l}\text { Содержание витамина } \mathrm{B}_{2} \\
\text { в белке, мкг/г }\end{array}$ & $2,5-3,0$ & 2,94 & 3,43 & 2,46 & 3,67 & 2,77 & 3,75 \\
\hline pH белка & $8,2-9,0$ & 8,13 & 8,17 & 8,15 & 8,18 & 8,13 & 8,15 \\
\hline pH желтка & $5,9-7,0$ & 6,19 & 6,20 & 6,23 & 6,25 & 6,22 & 6,26 \\
\hline Оплодотворенность, \% & не менее 90 & 95 & 100 & 100 & 95 & 90 & 90 \\
\hline
\end{tabular}


мкг/г) было у серебристой северокавказской породы.

Значение $\mathrm{pH}$ белка яиц у всех пород было незначительно ниже нормативного показателя, отклонения находились в пределах 0,020,07 ед.; $\mathrm{pH}$ желтка для всех пород находился в пределах нормы.

Оплодотворенность яиц переярых индеек всех пород находилось на хорошем уровне. Самый высокий уровень оплодотворенности наблюдался у белой северокавказской и серебристой северокавказской пород - 100\%; у бронзовой северокавказской и московской белой - 95\%; у узбекской палевой и черной тихорецкой пород - 90\%. Оплодотворенность обеспечивалось искусственным осеменением индеек. Следует отметить, что морфологические и биохимические показатели качества инкубационных яиц переярых индеек, в основном, соответствовали предьявляемым требованиям.

В 2019 г. в 12 селекционных партиях из инкубационных яиц был воспроизведен суточный молодняк индюшат основного и нового генофонда. В результате инкубации получен молодняк для расширения поголовья генофонда, увеличения популяции красных (рис. 1) и голубых (рис. 2) индеек, для испытаний межпород-

\begin{tabular}{|c|c|c|c|c|c|c|}
\hline \multirow{2}{*}{$\begin{array}{c}\text { Породы } \\
\text { основного } \\
\text { генофонда }\end{array}$} & \multicolumn{2}{|c|}{$\begin{array}{l}\text { Суточный } \\
\text { молодняк }\end{array}$} & \multirow{2}{*}{$\begin{array}{c}\text { Сохран- } \\
\text { ность } \\
\text { до } 16 \\
\text { нед., \% }\end{array}$} & \multirow[b]{2}{*}{ Пол } & \multicolumn{2}{|c|}{$\begin{array}{c}\text { Молодняк } \\
\text { в возрасте } 16 \text { нед. } \\
\end{array}$} \\
\hline & $\begin{array}{c}\text { коли- } \\
\text { чество, } \\
\text { гол. } \\
\end{array}$ & $\begin{array}{l}\text { живая } \\
\text { масса, г }\end{array}$ & & & $\begin{array}{l}\text { живая } \\
\text { масса, кг }\end{array}$ & $\begin{array}{l}\text { мясная } \\
\text { оценка, } \\
\text { баллы } \\
\end{array}$ \\
\hline \multirow{2}{*}{$\begin{array}{l}\text { Бронзовая } \\
\text { северокавказская }\end{array}$} & \multirow{2}{*}{890} & \multirow{2}{*}{57,8} & \multirow{2}{*}{89,1} & $0^{\pi}$ & $5,08 \pm 0,088$ & $4,23 \pm 0,063$ \\
\hline & & & & 우 & $3,57 \pm 0,044$ & $4,19 \pm 0,061$ \\
\hline \multirow{2}{*}{$\begin{array}{l}\text { Белая } \\
\text { северокавказская }\end{array}$} & \multirow{2}{*}{659} & \multirow{2}{*}{58,1} & \multirow{2}{*}{88,9} & $0^{2}$ & $5,54 \pm 0,130$ & $4,47 \pm 0,07$ \\
\hline & & & & 우 & $4,18 \pm 0,070$ & $4,82 \pm 0,057$ \\
\hline \multirow{2}{*}{$\begin{array}{l}\text { Серебристая } \\
\text { северокавказская }\end{array}$} & \multirow{2}{*}{699} & \multirow{2}{*}{52,9} & \multirow{2}{*}{89,7} & $0^{2}$ & $4,98 \pm 0,096$ & $4,24 \pm 0,064$ \\
\hline & & & & 우 & $3,39 \pm 0,075$ & $4,08 \pm 0,089$ \\
\hline \multirow{2}{*}{ Московская белая } & \multirow{2}{*}{539} & \multirow{2}{*}{58,7} & \multirow{2}{*}{88,1} & $0^{2}$ & $5,63 \pm 0,126$ & $4,55 \pm 0,075$ \\
\hline & & & & q & $4,35 \pm 0,082$ & $4,86 \pm 0,057$ \\
\hline \multirow{2}{*}{ Узбекская палевая } & \multirow{2}{*}{750} & \multirow{2}{*}{57,1} & \multirow{2}{*}{88,7} & $0^{\pi}$ & $5,10 \pm 0131$ & $4,18 \pm 0,085$ \\
\hline & & & & q & $3,44 \pm 0,073$ & $4,12 \pm 0,97$ \\
\hline \multirow{2}{*}{ Черная тихорецкая } & \multirow{2}{*}{605} & \multirow{2}{*}{56,0} & \multirow{2}{*}{87,9} & $\sigma^{\pi}$ & $4,82 \pm 0,102$ & $4,0 \pm 0,062$ \\
\hline & & & & q & $3,08 \pm 0,076$ & $3,79 \pm 0,075$ \\
\hline
\end{tabular}

\begin{tabular}{|c|c|c|c|c|c|c|}
\hline \multirow{2}{*}{$\begin{array}{c}\text { Популяции } \\
\text { нового } \\
\text { генофонда }\end{array}$} & \multicolumn{2}{|c|}{$\begin{array}{l}\text { Суточный } \\
\text { молодняк }\end{array}$} & \multirow{2}{*}{$\begin{array}{c}\text { Сохран- } \\
\text { ность до } \\
16 \text { нед., } \\
\%\end{array}$} & \multirow[b]{2}{*}{ Пол } & \multicolumn{2}{|c|}{$\begin{array}{c}\text { Молодняк в возрасте } \\
16 \text { недель }\end{array}$} \\
\hline & $\begin{array}{l}\text { количе- } \\
\text { ство, гол. }\end{array}$ & $\begin{array}{l}\text { живая } \\
\text { масса, г }\end{array}$ & & & $\begin{array}{l}\text { живая } \\
\text { масса, кг }\end{array}$ & $\begin{array}{l}\text { мясная } \\
\text { оценка, } \\
\text { баллы }\end{array}$ \\
\hline \multirow{2}{*}{ Голубые } & \multirow{2}{*}{477} & \multirow{2}{*}{55,3} & \multirow{2}{*}{87,5} & $0^{2}$ & $4,74 \pm 0,116$ & $4,20 \pm 0,092$ \\
\hline & & & & 우 & $3,10 \pm 0,079$ & $3,90 \pm 0,068$ \\
\hline \multirow{2}{*}{ Красные } & \multirow{2}{*}{57} & \multirow{2}{*}{57,2} & \multirow{2}{*}{87,0} & $0^{\pi}$ & $3,78 \pm 0,115$ & $3,80 \pm 0,200$ \\
\hline & & & & q & $2,22 \pm 0,165$ & $3,18 \pm 0,121$ \\
\hline \multirow{2}{*}{ Группа 602} & \multirow{2}{*}{604} & \multirow{2}{*}{57,0} & \multirow{2}{*}{90,0} & $0^{\pi}$ & $5,10 \pm 0,098$ & $4,33 \pm 0,079$ \\
\hline & & & & 우 & $3,53 \pm 0,087$ & $4,18 \pm 0,091$ \\
\hline \multirow{2}{*}{ Группа 607} & \multirow{2}{*}{889} & \multirow{2}{*}{61,7} & \multirow{2}{*}{89,7} & $0^{2}$ & $5,98 \pm 0,169$ & $4,58 \pm 0,074$ \\
\hline & & & & 우 & $4,18 \pm 0,107$ & $4,53 \pm 0,087$ \\
\hline
\end{tabular}

ных гибридов бронзовой северокавказской и белой широкогрудой пород (группы 607). Проведена бонитировка молодняка, данные представлены в табл. 3 и 4.

Количество суточного молодняка, закольцованного по породам, находилось в диапазоне
539-890 голов. Наименьшая живая масса суточных индюшат отмечалась у северокавказской серебристой породы - 52,9 г, наибольшая - у белой северокавказской $(58,1$ г) и у московской белой $(58,7$ г) пород. Наибольшую сохранность за период до 16 не-

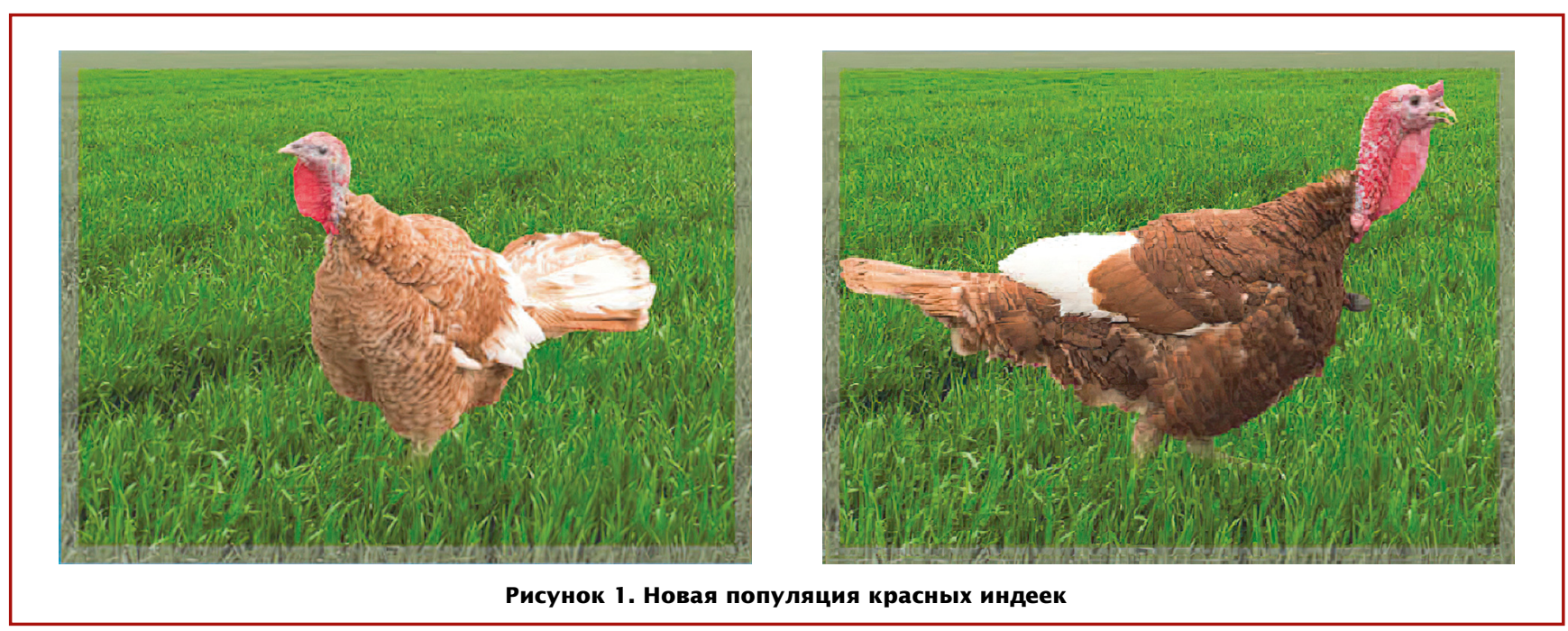




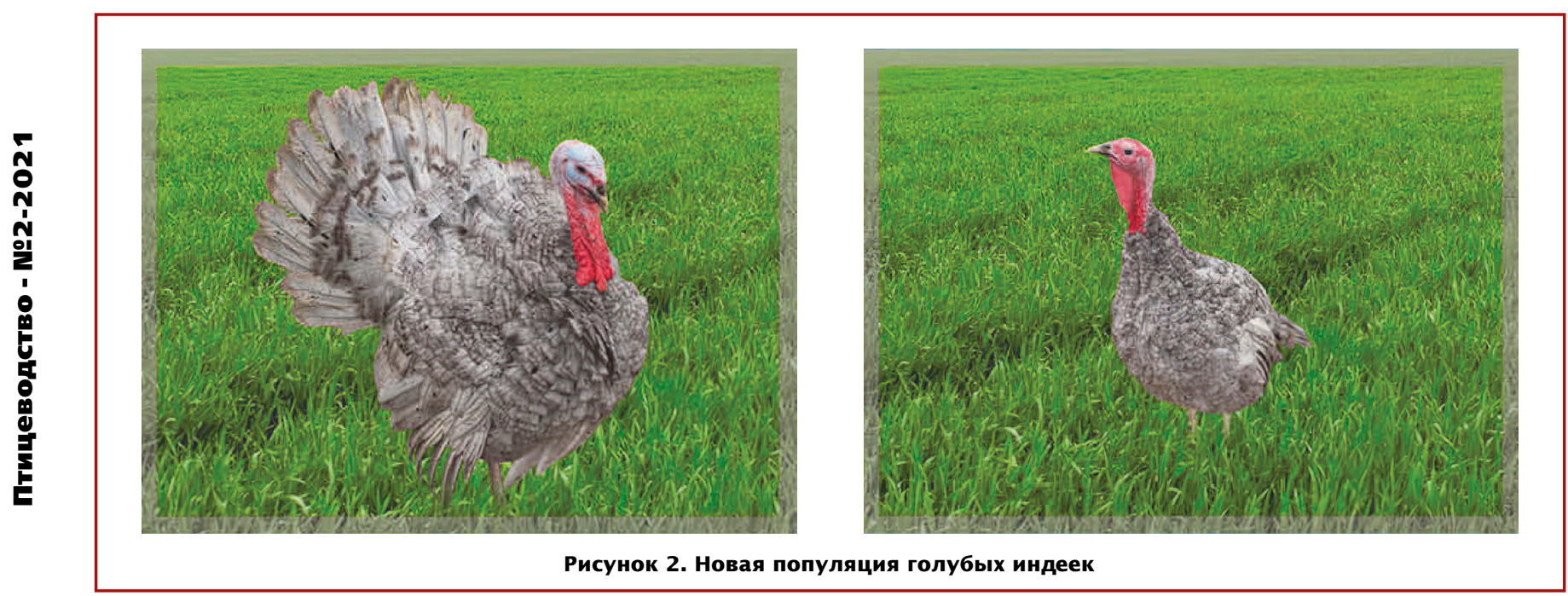

дель имели бронзовая северокавказская и серебристая северокавказская породы (89,1-89,7\%).

у индюшат-самцов в 16 недель лучший показатель по живой массе отмечен у белой северокавказской $(5,54$ кг) и московской белой $(5,63$ кг) пород. В этих же породах самцы имели высокую мясную оценку - от 4,47 до 4,55 балла. Самки этих пород среди своих сверстников также имели высокую живую массу (от 4,18 до 4,35 кг), мясная оценка была в пределах 4,82-4,86 балла.

Самую низкую живую массу и балльную мясную оценку в 16 недель имели самцы черной тихорецкой породы (4,82 кг и 4,0 балла); самки этой породы при живой массе 3,08 кг имели мясную оценку 3,79 балла.

Среди популяций нового генофонда отвод молодняка после инкубации составил от 57 до 889 голов. Самая высокая живая масса была отмечена у суточных индюшат 607 группы (61,7 г), самая низкая - у голубых индеек (55,3 г).

Высокой сохранностью за 16 недель обладали индюшата 602 (90\%) и 607 (89,7\%) групп. Живая масса индюшат-самцов в группе 607 была на уровне 5,98 кг при мясной оценке 4,58 балла, у самок - 4,18 кг при мясной оцен- ке 4,53 балла. Самцы популяции красных индеек в 16-недельном возрасте имели живую массу 3,78 кг и мясную оценку 3,8 балла; а самки - 2,22 кг и 3,18 балла. Исходя из вышеперечисленных данных, можно сказать, что каждая порода и популяция индеек индивидуальна по количественным и качественным характеристикам.

Заключение. На основании проведенных исследований можно заключить, что каждая порода и популяция индеек имеет свои индивидуальные продуктивные особенности и хозяйственно-полезные признаки. Эти особенности необходимо учитывать при дальнейшей селекционно-племенной работе по совершенствованию существующих и созданию новых высокопродуктивных генотипов индеек.

\section{Литература}

1. Давлеев, А.Д. Производство индейки в России в 2019 году // Птица и птицепродукты. - 2020. - №1. - С. 7-9. 2. Погодаев, В.А. Современные направления зарубежной и отечественной селекции индеек / В.А. Погодаев, С.С. Рябихин // Птица и птицепродукты. - 2020. - №1. - С. 40-43.

3. Шинкаренко, Л.А. Выведение новых отечественных генотипов индеек и их использование для получения экологически чистой продукции / Л.А. Шинкаренко, В.А. Погодаев. Черкесск, 2014. - С. 16-131.

4. Погодаев, В.А. Генетические параметры пород индеек, разводимых в ФГУП ППЗ «Северо-Кавказская 3ональная опытная станция по птицеводству» / В.А. Погодаев, В.А. Канивец, Л.А. Шинкаренко // Птица и птицепродукты. - 2013 . - №3. - С. 19-22. 5. Государственный реестр селекционных достижений, допущенных к использованию. Том 2. Породы животных. - ФГБНУ «Росинформагротех», 2016. - C. 172.

6. Методика проведения исследований по технологии производства яиц и мяса птицы / И.П. Салеева, В.П. Лысенко, В.Г. Шоль [и др.]. - Под общ. ред. В.С. Лукашенко и А.Ш. Кавтарашвили. - Сергиев Посад: ВНИТИП, 2015. - 51 с.

7. Яйца индеек инкубационные. Технические условия. ТУ 9844-00157150110-2015. - Обильное, 2015. $8 \mathrm{c}$.

8. Селекционно-племенная работа в птицеводстве / В.И. Фисинин, Я.С. Ройтер, А.В. Егорова [и др.]. - Сергиев Посад: ВНИТИП, 2016. - 250 с.

9. Комбикорма полнорационные для индеек. Технические условия. ТУ 10.91.10-00215613932-2017.

Обильное, 2017. - С. 2-18.

10. Руководство по оптимизации рецептов комбикормов для сельско- 
хозяйственной птицы / И.А. Егоров, Т.Н. Ленкова, В.А. Манукян [и др]. - Сергиев Посад: ВНИТИП, 2014. - 151 с.

11. Методическое руководство по кормлению сельскохозяйственной птицы / И.А. Егоров, В.А. Манукян, Т.Н. Ленкова [и др] - Сергиев Посад: вНИтип, 2015. - 198 с.

12. Оценка качества кормов, органов, тканей, яиц и мяса птицы: метод. рук-во для зоотехнических лаборато- рий / В.И. Фисинин, А.Н. Тишенков, И.А. Егоров [и др.]. - Под общ. ред. В.И. Фисинина и А.Н. Тишенкова. Сергиев Посад: ВНИТИП, 2010. - 105 с. 13. Информационный сборник по отечественному индейководству / Шинкаренко Л.А., Щербакова Н.Г., Шепляков А.В. [и др.]. - Обильное, 2018. - 25 с. 14. Наставления по сохранению и использованию биоресурсной коллекции сельскохозяйственной птицы /
В.И. Фисинин, Я.С. Ройтер, Д.Н. Ефимов [и др]. - Сергиев Посад: ВНИТИП, 2018. - 56 c.

Для контакта с авторами: Погодаев Владимир Аникеевич E-mail: pogodaev_1954@mail.ru Буравцова Ирина Николаевна Романенко Ирина Васильевна Колобова Ольга Евгеньевна Тел.: 8 (87951) 43-519

\title{
The Productive Performance, Morphological and Biochemical Egg Indices in Russian Turkey Breeds of Gene Pool Collection
}

\author{
Pogodaev V.A.', Buravtsova I.N. ${ }^{2}$, Romanenko I.V. ${ }^{2}$, Kolobova O.E. ${ }^{2}$ \\ ${ }^{1}$ North-Caucasian Federal Scientific Agrarian Center; ${ }^{2}$ Federal Scientific Center "All-Russian Research \\ and Technological Institute of Poultry" of Russian Academy of Sciences
}

Summary: The productive performance, morphological and biochemical egg indices in Russian turkey breeds of gene pool collection of the North-Caucasian Zonal Experimental Station for Poultry were determined in the molted hens in the beginning, middle, and finishing stages of the second season of lay. Six breeds of the gene pool and four new populations (blue, red, group 602, and group 607) were analyzed. Average hen weight at the beginning of lay in all 6 gene pool breeds exceeded the standards for the breeds. The highest average egg weight throughout the second season of lay was found in Bronze North-Caucasian breed (83.07 g). Shape indices of eggs in all 6 breeds fell within the range 68.53-72.93\%; Haugh units were 92.93-94.73\% and corresponded to the standards. Concentration of vitamin B2 in the albumen was normal in Bronze Nor-Caucasian and Uzbek Fauve breeds; in 3 breeds this parameter was above the normal range (by $0.43 \mathrm{\mu g} / \mathrm{g}$ in White North-Caucasian, by $0.67 \mathrm{\mu g} / \mathrm{g}$ in Moscow White, and by $0.75 \mathrm{\mu g} / \mathrm{g}$ in Black Tikhoretskaya breeds). The highest live bodyweight in males at 16 weeks of age was found in White North-Caucasian $(5.54 \mathrm{~kg})$ and Moscow White $(5.63 \mathrm{~kg})$ breeds; these breeds also featured the highest average scores of meat quality (4.47-4.55 scores out of 5). Among new populations the highest live bodyweight in males at 16 weeks of age was found in group 607 (5.98 kg).

Keywords: turkey, breeds, gene pool collection, productive performance, eggs for incubation, egg morphology, biochemical egg indices.

AGROVO

\section{Уважаемая Татьяна Анатольевна!}

От всей души поздравляем Вас, коллектив редакции, авторов и читателей журнала “Птицеводство” с 70-летним юбилеем!

Журнал по праву принадлежит к числу самых известных, популярных отечественных научно-производственных изданий. Все эти годы он был и остаётся в центре сельскохозяйственной жизни страны. Отрадно, что и сегодня одно из старейших отечественных изданий продолжает знакомить своих многочисленных читателей сактуальной информацией в отрасли птицеводства, информирует о новых технологиях, технике и оборудовании в птицеперерабатывающей промышленности, освещает различные мероприятия, выставки и семинары, связанные с отраслью и многое другое.

Достижения и успехи журнала - это результат, прежде всего профессионального мастерства журналистов, их внимания к проблемам отрасли и стремления способствовать их решению.

Пусть и впредь журнал “Птицеводство” радует читателей яркими и глубокими публикациями, интересными и полезными материалами.

Желаем Вам здоровья, новых творческих успехов, вдохновения, реализации намеченных планов и всего самого доброго! 